\title{
NEHÉZSÉGEKKEL SZEMBENI ELLENÁLLÓ KÉPESSÉG (REZILIENCIA) ÉS AZ ÉLETSTRATÉGIA ÖSSZEFÜGGÉSE FIATAL FELNỐTTEK POPULÁCIÓJÁBAN ${ }^{12}$
}

\section{BANDI SZABOLCS ${ }^{1}$ - CSÓKÁSI KRISZTINA ${ }^{1}$ - KÁLLAI JÁNOS ${ }^{1}$ - TIRINGER ISTVÁN ${ }^{2}-$ MARTIN LÁSZLÓ ${ }^{3}$ - KISS ENIKỐ CSILLA ${ }^{1}$}

\author{
${ }^{1}$ Pécsi Tudományegyetem Bölcsészettudományi Kar Pszichológia Intézet \\ ${ }^{2}$ Pécsi Tudományegyetem ÁOK Magatartástudományi Intézet \\ ${ }^{3}$ Kaposvári Egyetem, Pedagógiai Kar \\ E-mail: bandi.szabolcs@pte.hu
}

Beérkezett: 2019. március 30. - Elfogadva: 2020. február 14.

\begin{abstract}
Háttér és célkitûzés: a vizsgálat a lassú, ún. K-életstratégia és a nehézségekkel szembeni ellenálló képesség, valamint a szorongásérzékenység lehetséges összefüggéseit tárja fel. Evolúciós, pozitív és klinikai pszichológiai területeket ötvözố vizsgálatunk megközelitésmódja újdonságnak számít. Célunk a reziliencia és a $K$-stratégia közötti összefüggések vizsgálata.

Módszer: a papír-ceruza alapú tesztekkel végzett vizsgálatban hozzáférhetöségi egyetemista mintavételezés során 674 személy vett részt, önkéntes alapon. A résztvevók által kitöltött kérdốivcsomag a Connor-Davidson Reziliencia Kérdôivet, az Életstratégia Kérdōivet és a Szorongásérzékenység Indexet tartalmazták.

Eredmények: A korrelációs és lineáris regressziós statisztikai elemzések igazolták, hogy pozitín kapcsolat figyelhetố meg a lassú életstratégia és a reziliencia között. A szorongásérzékenység ugyanakkor negatív összefüggést mutat az említett változókkal. A nemi különbségek szintén megmutatkoznak, bár a minta jellemzói miatt ezek további vizsgálata szükséges.

Következtetések: Az eredményeink alapján elmondható, hogy a fiatal felnôttek esetén gyenge, ám szignifikáns kapcsolat áll fenn a K-életstratégia és a reziliencia között. Az életstratégiához tartozóan a reziliens személyek intim és tartós partnerkapcsolatokra törekednek, emellett kognitív szinten jellemzöjük az elörelátás, a tudatos és következetes tervezési képességek kibontakoztatása. A szorongásérzékenység bár helyenként statisztikailag szignifikáns kapcsolatot mutat a fenti változókkal, ezek mértéke sok esetben igen alacsony. A nemi különbségek releváns szempontként jelenhetnek meg, ám ezek tisztázásához a minta további bốvitése szükséges.
\end{abstract}

Kulcsszavak: reziliencia, életstratégia, tervezési képesség, intim párkapcsolatok, szorongásérzékenység

1 A vizsgálat a Helsinki deklaráció szellemében a kutatásetikai bizottság engedélye alapján zajlott (engedélyszám: 6732 PTE/2017).

2 A tanulmányt a NKFI K 120334 pályázat és az Emberi Erôforrások Minisztériuma ÚNKP-18-3-IV-PTE-96 kódszámú Új Nemzeti Kiválóság Programja támogatta. 


\section{BEVEZETÉS}

A kritikus életeseményekkel való szembesülés során átélt személyes tapasztalatok, az alkalmazott problémamegoldási módok alapvetôen befolyásolják a személyiségfejlôdés és a társas adaptáció kimenetelét. A családi vagy munkahelyi konfliktusok és traumák kellemetlen tapasztalatainak az életmódra, életstratégiára, személyiségfejlôdésre gyakorolt hosszú távú hatásait már számos tanulmány elemezte (De Robert, Barontini, Forcada, Carrizo és Almada, 2010; Cohen és mtsai, 2014; Marulanda és Addington, 2014; Sexton és mtsai, 2015; Pole, Dobson és Pusch, 2017). Az életvezetési krízisek megoldása előrejelzi a komoly nehézségekkel járó helyzetekkel való szembenézés várható kimenetelét. A problémakezelésnek azonban van egy személyesebb, individuális módja, amely a személy egyéni életútjához, saját családjához, barátaihoz és a fentiekben felsorolt társas forgatókönyvekhez való viszonyán alapszik. A konfliktusok és az esetlegesen megjelenô krízisek, illetve traumák megoldásával kapcsolatos személyes tapasztalatok nem csak egy életszakaszban, hanem az egész élet során alakítják a megterhelô helyzetekkel való megküzdés módjait, és ezen keresztül közvetlen hatással vannak a személy privát életvezetésére, szokásaira, testi és lelki egészségének alakulására. Ez a meghatározó beállítódás érvényesül a családalapításban, a gyermeknevelésben, az egyén társas és személyes kapcsolatainak kialakításában és fenntartásában, illetve az anyagi és a természeti eróforrások megteremtésében. Az életstratégia-választás szempontjából a személy két alternatíva között választhat, elsôsorban fogyasztó, a lehetôségeket kihasználó vagy ellenkezóleg, azokat létrehozó és megújító szerepben vesz részt a közös célok megvalósításában. A megközelítés egy régebb óta ismert populációbiológiai modellen, az r-K szelekció elméletén alapul (Bereczkei, 2003). Az r-stratégiák elsôsorban instabil és gyorsan változó környezetben jönnek létre („r” a populáció belsố növekedési rátájának jele), míg a K-stratégiák viszonylag stabil és bejósolható erôforrásokkal rendelkezô környezetben figyelhetôk meg („K” a környezet eltartóképességének a jele). Ennek megfelelő́en mind a gyors ( $r$-stratégia), mind a lassú stratégia (K-stratégia) adaptív lehet a környezet függvényében.

\section{Életstratégia}

Az életstratégia szerepét hangsúlyozó elméletek (Buss, 1997; Bereczkei, Birkas és Kerekes, 2007; Figueredo és mtsai, 2010; Figueredo és mtsai, 2017) kiemelik, hogy a konfliktusokkal, háborúkkal és traumákkal terhelt társadalmi szelekciót kísérô versenyben két, alapvetôen különbözô természetú életstratégiát támogató jellemzókkel rendelkezô csoportot különíthetünk el. A társas és anyagi erôforrásokhoz való hozzáférés, azok létrehozásában és megvédésében vállalt szerep, a közösen elóállított kulturális és anyagi javakból való részesedés szándéka alapján a lassú, ún. K-stratégiára jellemzô a befektetések hosszabb idejû megtérülésével számoló, hosszabb távra tervezô, a szociális fejlődésben kölcsönös karitatív tevékenységre berendezkedô mintázat. Az ettôl eltérô, azaz gyors, azaz r-stratégiát követôk a mások által előállított és védelmezett társas, illetve anyagi erőforrások feletti kontrollt kívánják gyakorolni: ók inkább fogyasztói szemlélettel rendelkeznek, mely során felélik az erôforrásokat anélkül, hogy 
a fogyasztott javak pótlásáról, utódaik gondozásáról, a közösségi javak pótlásáról gondoskodnának. A lassú és a gyors stratégiát követôk egyaránt fontos szerepet játszanak a társadalmi erôforrások mobilizálásában, idôszakos allokációjában. A K-stratégiát követôk a jövôbe vetett bizalommal, családi összetartásra összpontosítva és reményekkel telve várják erôfeszítéseik eredményeit. Az r-stratégia képviselői ugyanakkor rövid távú megtérülésre és a közvetlenül megélhetô haszonra, illetve a személyes eredményességre építenek. Az egyes stratégiákhoz eltérô motivációs és célrendszer kapcsolódik, amely mögött a szocioszexuális és szociökonómiai tényezôkön túl releváns nemi különbségek is meghúzódhatnak. Az utóbbi vonatkozásában a kutatások azt mutatják, hogy a nôk jellemzốen lassabb életstratégiát követnek a férfiakhoz képest (pl. Jonason, Koenig és Tost, 2010; McDonald, Donnellan és Navarrete, 2012), bár akadnak olyan vizsgálatok is, amelyekben nem találnak nemi különbséget az életstratégiát illetốen (pl. Sherman, Figueredo és Funder, 2013). Említést érdemel ugyanakkor, hogy a társadalmi követelményekhez illeszkedő nemi szerepek (gender) szélsôségeivel jellemezhetô társadalmak (markáns maszkulin és markáns feminin szerepek) fejlôdési potenciálja lényegesen kisebb. A K- és az r-szemléletet, valamint a nemi különbségeket egymással hatékonyabban integráló társadalmakban a stratégiák ${ }^{3}$ közötti hatékonyabb kommunikáció révén kulturális és gazdasági értelemben is jelentôsebb erôforrásokkal, nagyobb fejlôdési potenciállal számolhatunk (Schmitt és mtsai, 2017). A két életstratégia sikeres integrálása egy adott szúkebb vagy tágabb társas közösség alapvetô érdeke, mert elôsegíti a változatos és fejlôdési lehetôségeket gyarapító kognitív és affektív erôforrások kiaknázását, többek között például a társas területeken megnyilvánuló intelligencia fejlődését (Figueredo, Woodley of Menie és Jacobs, 2015).

Az életstratégia egyénre jellemzô, általában nem ölt szélsôséges formát. Hatása a párválasztáson, a szexuális partnerkeresésen, a kapcsolatépítésen, és a családalapításban való elkötelezettségen túl a testi és lelki betegségekben, szenvedélybetegségekben, fizikai és pszichikai fittségben egyaránt megjelenik. A gyors stratégiát képviselők nagyobb stressznek vannak kitéve, kiegyensúlyozatlanok, míg a lassú stratégiát követôket a kifejezettebb társas támogatás és a stabilabb környezet miatt alacsonyabb mértékú stressz veszi körül, így magasabb fokú boldogságról számolnak be (Del Giudice, Ellis és Schirtcliff, 2011). A lassú stratégiát képviselők felkészülnek a várható problémákra, társakat keresnek a megoldáshoz, hogy megakadályozzák azok kibontakozását, így elkerülik a stressz egy részét, de ezzel együtt a megelôzési erôfeszítések lekötik az energiáik jelentôs részét. Amennyiben a probléma mégis megjelenik, annak izolálására, megsemmisítésére törekednek, illetve problémaorientált aktív coping-mechanizmusokat alkalmaznak. Ennek a megoldásmódnak a szélsôségei gyakran vezethetnek a túlbiztosítás vagy a túlzott ragaszkodás (pl. szabályokhoz), rigiditás különbözô viselkedési formáinak alkalmazásához (Tops, 2014). A tervezés és az ahhoz hú végrehajtás, az elôkészítés-megvalósítás egysége fontos része ennek a stratégiának (Figueredo és mtsai, 2006). Ezzel

\footnotetext{
A K-r stratégia definíciója biológiai természetû. Az „r” stratégiát követổ a reprodukciós ráta növelésére, több utód nemzésére törekszik, a „K” stratégia képviselôje ugyanakkor az életvitel szempontjából a gondozási kapacitás növelését tartja fontosnak. A két forma tehát más-más megoldást választ a fizikai és társas környezetben zajló küzdelemben a túléléshez. A társas viselkedés szervezôdésének hatékonyságát mutató neuropszichológiai megközelítésekről Kállai (2013) munkájában részletesebb adatok találhatók.
} 
szemben a gyors stratégiát képviselôk bevárják, sôt kompetitív törekvéseikkel gyakran elố is idézik a konfliktust, majd a megoldásra nagy emocionális és fizikai energiát összpontosítanak, hogy minél hamarabb és végérvényesen túl legyenek rajta. Természetesen van olyan környezet, amelyben ez a legadaptívabb válasz, amely által tisztázódnak és rendezôdnek az esetlegesen megbomlott erôviszonyok (Del Giudice és mtsai, 2011). A birtoklás, az elônyszerzés, a fokozott versengéssel járó stressz és az ehhez kapcsolódó impulzivitás sokszor megfelelố eredményre vezet, de a családi kapcsolatokban, munkahelyi közösségekben, baráti viszonyokban számos konfliktust okozhat (Jonason, Koenig és Tost, 2010; Van der Linden, Dunkel, Tops, Hengartner és Petrou, 2018).

$\mathrm{Az}$ életstratégia mérési lehetôségei sokfélék: építhetünk életvezetési interjúkra, életeseményeket felsoroló listákra, valamint kérdôíves eljárásokra. Napjainkban a legátfogóbb és pszichometriailag megfelelô reliabilitással és validitással rendelkezô életstratégia-mérőeszköz kidolgozása Figueredo és mtsai (2006) nevéhez fúzôdik. A kérdôív a tervezô- és kontrollképességet, a szülőkkel való kapcsolat minôségét, a társas támogatás mértékét, az intim társkapcsolatok jellegét, valamint az altruizmussal és a vallásossággal kapcsolatos elkötelezettséget méri fel. Jelen vizsgálatban a kérdôívvel kapott adatok, valamint a szorongásérzékenység és a reziliencia kapcsolatának vizsgálatát tûzzük ki célul.

\section{Reziliencia}

A reziliencia egy bekövetkezô negatív eseménnyel szemben megjelenô rugalmas reakciómódot jelent, amellyel a történés negatív következményei kivédhetôvé válnak. A veszélyeztetố tényezô lehet családi körülményekbôl fakadó, mint például a szülook mentális betegsége, vagy a családon belüli erôszakos bántalmazás bármely formája, illetve a család egyéb szempontból tekintett hátrányos helyzete (Werner és Smith; 1992, 2001). A veszélyeztetố tényezôk ugyanakkor származhatnak a családon kívülrôl is, így ezek okai lehetnek akár természeti katasztrófák - pl. földrengés, cunami vagy az éghajlatváltozásból fakadó természeti katasztrófák -, de a háborúk, illetve egyéb poszttraumás zavarral járó további helyzetek is idesorolhatók. Werner és Smith (2001) kutatásukban a rezilienciát „legyôzhetô sérülékenységnek” nevezik, amelyben a kockázati tényezóket a védőfaktorok ellensúlyozni képesek. A szerzôknek köszönhetô, hogy a reziliencia multidimenzionális konstruktummá vált, melyet három fố tényezôcsoport határoz meg. A védôfaktorok elsố csoportja a személyiségbôl ered, vagyis bizonyos tényezôk jelenléte elôsegíti a lelki ellenálló képesség adaptív múködését. Eszerint fontosak a fejlett kognitív képességek, az érzelmi és viselkedésszabályozási mechanizmusok, a tehetség különbözô megnyilvánulásai, az élet értelmességébe vetett hit, az önbizalom, a külsố megjelenés, a hit és az optimizmus. A második csoportban a család protektív faktorai szerepelnek, elsố helyen a bizalommal teli anya-gyerek kapcsolat, az anya iskolai végzettsége és a kiterjedt családi háló. A harmadik csoportba a társas-társadalmi környezet védőfaktorait sorolták be, ezek között említésre került többek között az iskolához való kötôdés, a kompetens mentor szerepe, illetve a a közösségi tevékenységekben való részvétel, a különbözô közösségekbe való beágyazottság. A multidimenzionális megközelítés számos aspektusát Masten, Best és Garmezy (1990) is megerôsítették, akik 
szerint a reziliencia nem más, mint a veszélyeztetett életkörülmények ellenére történó sikeres alkalmazkodás. A reziliencia definiálására számos további megfogalmazás született, így Caffo és Belaise (2003) szerint a reziliencia a pozitív emberi fejlődésnek és a stresszorokkal való megküzdés képességének a következménye. A rezilienciakutatások eredményeit összegezve elmondható, hogy a konstruktum azon személyes és környezeti tényezôket foglalja magába, amelyek elôsegítik a veszélyeztetett életkörülmények ellenére történô sikeres alkalmazkodást, enyhítik a stressz negatív hatásait, és lehetôvé teszik a változásokkal történó adaptív megküzdést. A reziliencia emellett az egyéni megküzdési módokat próbára tévô fokozott stresszt követôen a normál múködéshez való visszatérés képességét is jelöli (Ahern, Kiehl, Sole és Byers, 2006; Norris, Stevens, Pfefferbaum, Wyche és Pfefferbaum, 2008). Carle és Chassin (2004) továbbá arra is rámutattak, hogy azok az egyének, akik magas szintú rezilienciáról adnak számot, nagyobb valószínúséggel élnek meg pozitív érzelmeket a kedvezôtlen élethelyzetekkel történô coping során. A rezilienciát emellett különbözô genetikai (Tannenbaum és Anisman, 2003), biológiai (Charney, 2004), pszichológiai (Campbell-Sills, Cohan és Stein, 2006) és környezeti (Haskett, Nears, Ward és McPherson, 2006) tényezôk határozzák meg, aminek következtében mára a reziliencia konstruktuma egy többdimenziós, interaktív és dinamikus modellé vált, melyben a korábban említett személyes, családi és környezeti tényezók egyaránt szerepet játszanak.

A reziliencia és az életstratégiák különbözó változatainak bemutatása után megállapíthatjuk, hogy a K- és r-stratégia alapvetôen befolyásolja nem csak az egyén, de az általa képviselt közösségen keresztül nagyobb társadalmi csoportok fejlôdési potenciálját, továbbá mentális és szomatikus állapotát. Az evolúciós pszichológiában leírt kétféle életstratégia és a reziliencia viszonyát a fentiek alapján indokolt vizsgálni, amely az egyéni és társas stresszhelyzetek kezelésének különbözô módozataira, forgatókönyveire mutathat rá. Vizsgálatunkban e két jelenség összefüggéseit vettük górcsố alá, figyelembe véve a két fogalom egészségpszichológiai jelentôségét, rövid és hosszú távú hatását a személy pszichés és akár fizikai jóllétére a társas alkalmazkodás perspektívájának bevonásával.

\section{Szorongásérzékenység}

A vizsgálatunkban ugyan csupán kiegészítô, közvetítô szerepben jelenik meg a szorongásérzékenység jelensége, de úgy véljük, néhány gondolat erejéig érdemes és fontos kitérnünk a kérdéskör bevezetô jellegú pszichológiai ismereteinek az áttekintésére. A szorongásérzékenység (angolul anxiety sensitivity, AS) definíció szerint olyan félelemérzet, amely a szorongással együtt járó testi tünetekre, illetve magára a szorongás szubjektív tapasztalataira vonatkozik (Kerekes, 2012). A félelem oka jellemzóen abban keresendô, hogy a személy erôteljesen tart attól, hogy a szorongásos tünetek jelentôs maladaptív hatást fejthetnek ki az élete valamennyi (pszichés, fizikai és szociális) területén.

Az empirikus kutatások számos területen demonstrálták a szorongásérzékenység lélektani relevanciáját. Lebeaut, Tran és Vujanovic (2020) tûzoltók által átélt poszttraumás stressz (PTSD), illetve az alkoholabúzus kapcsolatában igazolták a szorongásérzé- 
kenység részleges szerepét a megküzdési motivációk maladaptív befolyásolása kapcsán. Az egyetemisták körében megfigyelhetô nagymértékú impulzív alkoholfogyasztást szintén erôteljesen bejósolta a szorongásérzékenység mértéke (Paulus és Zvolensky, 2020), míg Otto és munkatársai (2016) szemléletesen világítottak rá a szorongásérzékenység és a munkamemória interaktív kapcsolatának szerepére a negatív jellegú egészségmagatartás hátterében. Kalantar és mukatársai (2019) szintén a tûzoltók esetében tapasztalt PTSD tünetek kapcsolatát kívánták feltárni a szorongásérzékenység viszonyában, ám itt a reziliencia kérdésköre is fókuszba került. Eredményeik alapján megállapítható, hogy míg a szorongásérzékenység önmagában és más tényezókön keresztül is ki tudta fejteni a (maladaptív) hatását, addig a reziliencia esetén az adaptív hatás alacsonyabb mértékben és csupán közvetlen módon bizonyult szignifikánsnak. Lies és munkatársai (2017) szintén kimutatták PTSD esetén a reziliencia és a szorongásérzékenység - ellentétes elôjelû - hatását, ahol a reziliencia szintén közel feleakkora mértékében bizonyult protektív faktornak, szemben a szorongásérzékenységgel.

Az élettörténeti stratégia és a szorongásérzékenység viszonyában jelen kutatás úttörố jellegûnek tekinthetô: a szerzôk elôtt nem ismert korábbi rendelkezésre álló, szigorúan ezt a két konstruktumot a fókuszába helyező kutatás.

A fentiekben leírtak alapján feltételezzük, hogy

- H1: a K-életstratégia mértékében a nemek között különbség figyelhető meg;

- H2: a reziliencia pozitív együttjárást mutat a K-típusú életstratégia preferenciájával és negatív irányú kapcsolatot a szorongásérzékenységgel;

- H3: a reziliencia mértékével kapcsolatot mutat a K-stratégia (3.1.) tervezés és kontrollképessége, valamint a család (3.2.) és a kortársak (3.3.) részéről érkező társas támogatás mértéke, illetve a romantikus párkapcsolat minősége (3.4.).

\section{MÓDSZEREK}

\section{Személyek, eljárásmód és etikai vonatkozások}

A reziliencia és az életstratégia kérdôívekkel végzett felmérés egy nagyobb, az énhatárok hatékonyságával foglalkozó kérdôíves projekt részeként valósult meg. A rendelkezésünkre álló, hiánytalanul kitöltött kérdôívek alapján 674 személyt vontunk be az elemzésbe. A populáció felmérése anonim, papír-ceruza alapú, hozzáférhetôségi mintavételi eljárás segítségével zajlott. Az adatfelvételben a kaposvári és a pécsi egyetemek különbözô fakultásainak graduális és posztgraduális nappali és levelezô képzésében részesülô hallgatók vettek részt. A jelen tanulmány elemzéseibe bevont kitöltôk 71,2\%-a nô. A résztvevók életkora tág tartományban szórt: az átlagéletkor 25,7 év, a szórás pedig 7,9 év; a legfiatalabb kitöltô 18, míg a legidôsebb 49 éves. A kérdốvek kitöltésére csoportosan vagy egyénileg került sor, több más önjellemzô kérdôív felvételével együtt. A vizsgálat a Helsinki deklaráció szellemében, a kutatásetikai bizottság engedélye alapján zajlott (engedélyszám: 6732 PTE/2017). 
A Reziliencia Kérdôív (Connor és Davidson, 2003; Davidson és Connor, 2017) a streszszel való sikeres megküzdés mérésére kidolgozott, 25 itemból álló mérôeszköz.

A jelen mintában a Connor és Davidson által jóváhagyott magyar fordítást és az általunk több publikációban is említett összesített pontértékre hagyatkozó értékelés mellett a több publikációban is idézett ötfaktoros értékelési változatot alkalmaztuk (Kiss és mtsai, 2015). Mintánkban az elsố rendú faktor Cronbach-értéke $\alpha=0,90$. Az alfaktorok statisztikai mutatói (zárójelben a belsố konzisztenciát kifejezô Cronbach-alfa értéke): I. Kitartás, személyes kompetencia $(0,87)$ (pl. „Dolgozom azért, hogy elérjem a céljaimat."); II. Nehézségek ellenére megtartott belsố kontroll, kognitív és érzelmi önszabályozás $(0,84)$ (pl. „Úgy érzem, én irányítom az életemet.”); III. Adaptációs törekvés aktív megküzdéssel, a változások respektusa $(0,58)$ (pl. „Képes vagyok arra, hogy alkalmazkodjak a változásokhoz.”); IV. Szociális háttértámogatás biztosítása $(0,57)$ (pl. „Vannak közeli és biztonságot nyújtó kapcsolataim. ”); V. Az események értelmezésére való törekvés, értelemkeresés, spiritualitás $(0,59)$ (pl. „Mindennek megvan az oka. ”). A kérdôív kitöltése során a résztvevôk ötfokú Likert-skálán ( 0 = egyáltalán nem igaz; 4 = szinte mindig igaz) értékelik az egyes tételeket. A kérdôívben elért összpontszámok 0-100 közötti tartományba sorolhatók.

Életstratégia Kérdôív (Life History Strategy) rövidített formája (K-SF-42, Figueredo és mtsai, 2017). A K-SF-42 (Figueredo és mtsai, 2017) egy korábbi, hosszabb Arizonai Életstratégia Történeti Leltár rövidített változata, amely a K- és r-stratégiák alkalmazásának mértékét mutatja meg, ahol a magasabb pontérték fejezi ki a K-stratégia alkalmazásának fokozottabb mértékét. A magyar adaptáció során Birkás és mtsai (2018) egy korábbi rövidített változattal is végeztek e tárgyban vizsgálatot. (A jelenlegi hoszszabb magyar változat a Pécsi Tudományegyetem Kognitív Idegtudományi Laboratórium közremúködésével készült, Kállai János és Dorn Krisztina munkája.) A kérdôív statisztikai mutatói kiválók, a tételek az alábbi hét faktorba sorolódnak (zárójelben egy-egy példatétel és a belsố konzisztenciát kifejezô Cronbach-alfa értékei találhatók meg): I. Családdal való kapcsolat és a részükrôl biztosított támogatás (pl. „Hányszor említették a rokonai, hogy valamit jól csinált?”; 0,81); II. Vallásosság (pl. „A vallás fontos az életemben.”; 0,85); III. Intim, romantikus társkapcsolat (pl. „Aggódom, hogy a partnerem nem szeret annyira, mint én ôt." [fordított tétel]; 0,92); 0,92); IV. Tervezés és kontrollképesség (pl. „Úgy vélem, a legtöbb nehéz helyzetbôl tanulok valami jelentôset.”; 0,86); V. Baráti kapcsolatok és a részükrôl megnyilvánuló támogatás (pl. „Milyen gyakran fejezték ki a barátai a gyöngédségüket?”; 0,87); VI. Anyával és apával való kapcsolat minôsége (pl. „Mennyi mindent tanított Önnek az édesanyja az életról?”; 0,81); VII. Altruizmus (pl. „Jelenleg nagymértékben hozzájárulok a hozzátartozóim boldogulásához és jóllétéhez. ”; 0,94). A válaszadás a II., III., IV., VII. faktorok esetén -3 (= Nagyon nem értek egyet) és +3 (= Nagyon egyetértek) értékek közötti Likert-skálával, míg az I., V., VI. faktorokban a 0 (= Nem tudom / Nem vonatkozik rám) és 3 (= Sokat) közötti értékek közül választva történik. Ezt az eredeti verzióból származó jelölési hagyományt az magyarázza, hogy a kérdôív kétféle kérdéstípust tartalmaz: a II., III., IV. és VII. faktorok esetén a tételek állítás formájában vol- 
tak meghatározva, míg az I., V. és VI. faktorhoz kapcsolódó tételek kérdô formájúak. Továbbá fontos kiemelnünk a teszt Intim romantikus társkapcsolatok faktorát, mely kizárólag fordított tételeket tartalmaz (ld. pl. a példatételt). Tehát az értelmezése - az eredeti teszt értelmezési módszertanával megegyezô módon - fordított a többi alkomponenssel összevetve: az alacsony értékek jelentik a bizalommal teli, kiegyensúlyozott intim társkapcsolatokat, míg a magas értékek ennek ellentettét. A teszt angol nyelvú változata megtalálható ${ }^{4}$ Figueredo és mtsai (2017) publikációjában.

Szorongásérzékenység Index (Anxiety Sensitivity Index (ASI, Reiss, és mtsai, 1986, magyar verzió: Kerekes, 2012). Az ASI (Reiss, Peterson, Gursky és McNally, 1986, magyar verzió: Kerekes, 2012) 16 tételbôl áll, melyek esetében a válaszadó ötfokú skálán ( 0 = nem zavaró - 4 = nagyon zavaró) értékeli a szorongáshoz köthetô tüneteket. Az ASI a különbözô szorongásos zavarokra vonatkozó vulnerabilitást jelzi (Deacon és Abramowitz, 2006) a következô három faktor segítségével: I. Fizikai, szomatikus tünetekhez kötôdő aggodalmak (pl. „A szokatlan testi érzetek megijesztenek.”), II. Mások által is megfigyelhetô tünetek miatti szociális jellegú aggodalmak (pl. „Fontos, hogy ne látszak idegesnek.”), III. Kognitív jellegú zavarokkal kapcsolatos aggodalmak (pl. „Amikor nem tudom a figyelmemet egyetlen feladatra összpontosítani, aggódom, hogy esetleg megbolondulhatok.”). Az alacsony tételszám miatt a faktorok közötti diszkriminációs érték gyenge, ezért sokszor egyfaktoros, általános szorongásos vulnerabilitást jelzô eszközként használják. Ennélfogva a jelen vizsgálat során a szorongásérzékenység felmérésére csak az ASI összpontszámát alkalmazzuk (a mintában mért Cronbach $\alpha=0,89$ ).

\section{Adatelemzés}

A vizsgálatból származó adatok elemzése három statisztikai szoftver segítségével történt: az IBM SPSS Statistics 25, a jamovi 0.9.5.16, illetve a JASP 0.9.2.0 programok tartalmában azonos, csupán formátumában különbözô adatbázison végezték el a szükséges múveleteket. A többplatformos megoldás alkalmazása egyrészt lehetôvé tette a magasabb szintú megbízhatóság garantálását, másrészt egymást kiegészítve tudtak megoldással és válasszal szolgálni a felmerülô vizsgálati kérdésekre és hipotézisekre. Az elemzések megkezdése elốtt a vizsgálati változókon normalitásvizsgálatot végeztünk annak meghatározására, hogy a statisztikai próbák parametrikus vagy nem parametrikus családja kerüljön alkalmazásra. Az adatok értékelése során Spearman korrelációs, valamint lineáris regressziós eljárásokat alkalmaztunk. A Saphiro-Wilk-próba az összes változó esetén szignifikáns eredményt mutatott $(\mathrm{p}<0,001)$, azaz a vizsgált konstruktumok a fentiekben megnevezett eszközökkel mért értékeinek eloszlása nem tekinthetô normálisnak. Kivételt képez az Életstratégia Kérdôív összesített értéke $(p=0,499)$, mely megfelel a normál eloszlás kritériumainak. Ennek fényében a választásunk a nem parametrikus próbákra esett az adatelemzés további fázisaiban.

4 A magyar nyelvű fordítás a jelen publikáció első szerzőjén keresztül hozzáférhető. 


\section{EREDMÉNYEK}

\section{Az Életstratégia Kérdōiv megerôsitő faktorelemzése}

Tekintetbe véve, hogy az Életstratégia Kérdôívnek a vizsgálatban használt formáját illetôen nem áll rendelkezésre hivatalos hazai adaptációja, megerôsítô faktorelemzéssel (Confirmatory Factor Analysis - CFA) vizsgáltuk meg a mérôeszköz struktúráját. Az adataink nem normális eloszlásából fakadóan a robusztusnak tekintett WML (Weighted Maximum Likelihood) becslési módszert alkalmaztuk (ld. pl. Field és Smith, 1994). Három modellt állítottunk fel: az elsô (M1) a teszt nemzetközileg elfogadott faktorstruktúráját jelenítette meg, a második (M2) a módosítási indexek figyelembevételével történt megváltoztatott tételbeosztást vizsgálja, míg a harmadik (M3), végsố faktorstruktúrát a tételek közötti kovarianciakapcsolatok és a másodrendú faktor bevonásával értük el. Az M3 illeszkedési mutatói a strukturális egyenlet modellezés (SEM) általános elvei alapján elfogadhatónak tekinthetôk: $\chi^{2}=1828,4 ; \mathrm{df}=767 ; \chi^{2} / \mathrm{df}$ $=2,382 ; \mathrm{CFI}=, 906 ; \mathrm{TLI}=, 900 ; \mathrm{RMSEA}=, 052$. A végsố modellünk egymással korreláló faktorokat feltételezett, ami túlnyomó részben helytállónak is bizonyult. (Ez alól kivételt csupán a vallásosság faktor képez.) További adatokért ld. az 1. és 2. táblázatokat.

1. táblázat. A megerôsítô faktorelemzés alternatív modelljeinek illeszkedésmutatói

\begin{tabular}{lccccccccc} 
& $\chi^{2}$ & df & $\chi^{2} /$ df & CFI & TLI & RMSEA & CI $^{\text {RMSEA }}$ & AIC & BIC \\
\hline M1 & 3375,7 & 798 & 4,230 &, 812 &, 798 &, 073 & $0,070-0,075$ & 70363 & 71010 \\
M2 & 3059,9 & 798 & 3,834 &, 835 &, 822 &, 068 & $0,066-0,071$ & 70047 & 70694 \\
M3 & 1828,4 & 767 & 2,383 &, 906 &, 900 &, 052 & $0,049-0,055$ & 58591 & 58988 \\
\hline
\end{tabular}

Megjegyzés: AIC - Akaike információs kritérium; BIC - Bayes-féle információs kritérium; RMSEA - a becslés négyzetes középérték hibája; CFI - összehasonlító illeszkedési mutató; TLI - Tucker-Lewis-index

A modellek összehasonlítása során fény derült arra, hogy az eredeti, nemzetközi gyakorlatban alkalmazott faktorstruktúrától egy tétel esetén tér el a hazai megoldás: a 42. tétel nem mutatott statisztikailag szignifikáns töltést egyik faktor esetén sem, így ezt kihagytuk a további elemzésekbool. Ezeken túl releváns és erôteljes kovarianciakapcsolat volt megfigyelhetô a 13. és 14. tétel esetén („Vallásosság” faktor: „Nagyon vallásos ember vagyok.” - „A vallás fontos az életemben. ”); az 5. és 6 . tétel viszonyában („Tervezés és kontrollképesség” faktor: „Általában még akkor is felfedezem a dolgoknak a derüs oldalát, ha úgy tünik, minden rosszul alakul.” - „A legrosszabb helyzetekben is találok valami pozitivat.”), a 28. és 29. („Mennyi szeretetet és gyöngédséget adott Önnek az édesapja a felnövekedése során?”- „Mennyi idôt és figyelmet fordított Önre az édesapja, amikor Önnek szüksége volt rá??), illetve a 29. és a 30. tétel (,Mennyi idôt és figyelmet fordított Önre az édesapja, amikor Önnek szüksége volt rá?” - „Mennyi mindent tanitott Önnek az Édesapja az életról?”) között („Anyával és az apával való kapcsolat minôsége” faktor), valamint a 11. és 12. tétel vizsgálatakor („Altruizmus” faktor: „Havonta sok idôt töltök szervezett önkéntes munkával az iskolában vagy más ifjúsági szervezetek körében.” - „Gyakran járulok hozzá más szervezetek, gyújtések, jótékonysági kezdeményezések müködéséhez [beleértve a havi fizetéslevonással járó 


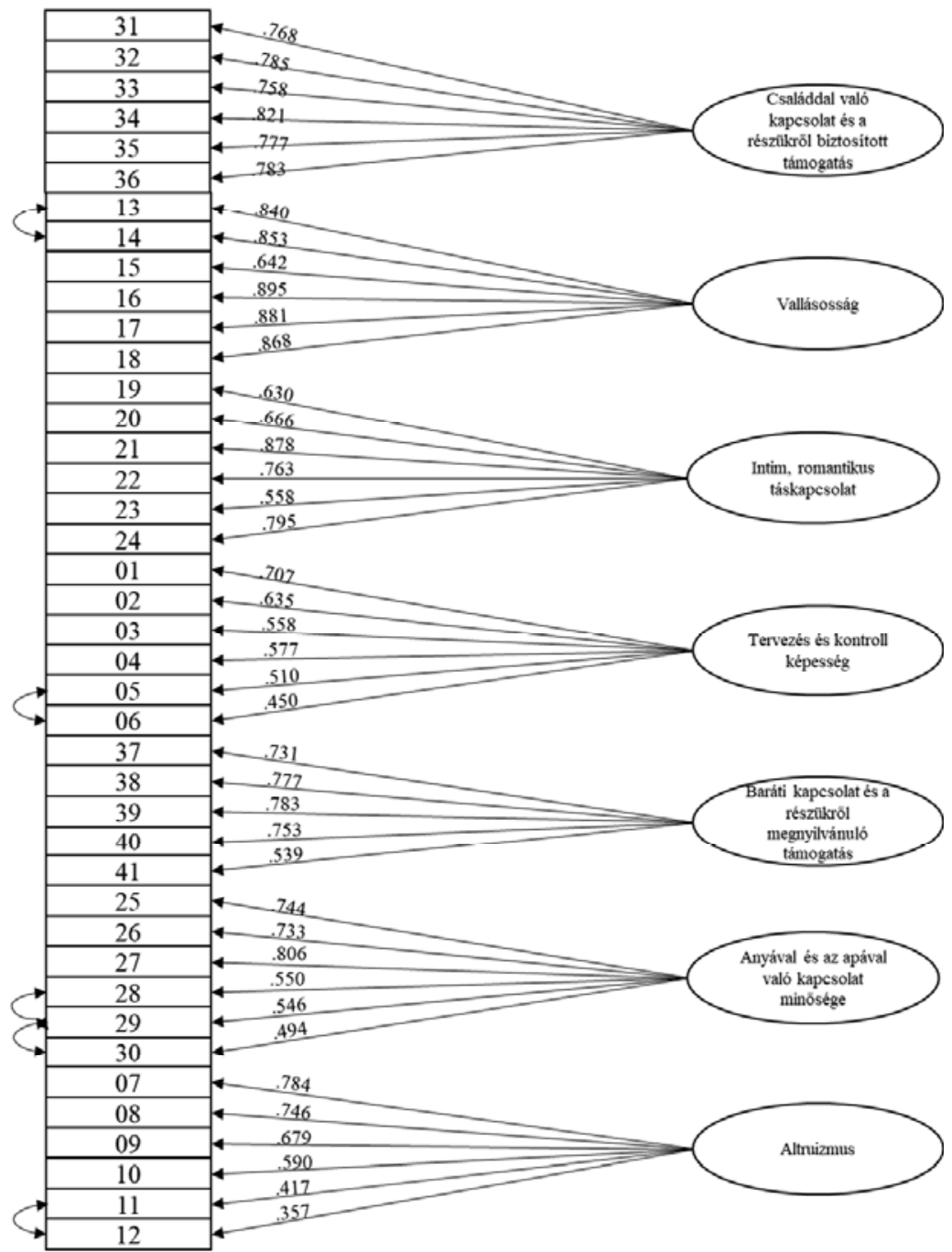

1. ábra. Az Életstratégia Kérdôív megerôsítô faktorelemzésének eredményei

Megjegyzés: Az ábra átláthatósága érdekében a faktorok közötti kovarianciakapcsolatok nem kerültek feltúntetésre, ezek részletes adataiért ld. a 2. táblázatot.

adományozást is]. "). A részletes faktorstruktúrát lásd az 1. ábrán. Összességében tehát elmondható, hogy apró módosítással ugyan, de sikerült túlnyomórészt reprodukálni a kérdőív eredeti faktorstruktúráját, ami így alkalmassá teszi a nemzetközi összehasonlításokra is. 
2. táblázat. Az Életstratégia Kérdôív faktorainak kovarianciamátrixa és a másodrendú faktorba való töltésük mértéke

\begin{tabular}{lrrrrrrr} 
& 1 & 2 & 3 & 4 & 5 & 6 & 7 \\
\hline $\begin{array}{l}\text { 1. Családdal való kapcsolat és a } \\
\text { részükról biztosított támogatás }\end{array}$ &, 796 & & & & & & \\
2. Vallásosság & $\mathbf{5 , 3 9 2}$ & $\mathbf{, 1 2 7}$ & & & & & \\
3. Intim, romantikus párkapcsolat & $\mathbf{- 9 , 2 1 1}$ & $\mathbf{9 , 6 0 5}$ & $\mathbf{- , 2 6 8}$ & & & & \\
$\begin{array}{l}\text { 4. Tervezés és kontrollképesség } \\
\text { 5. Baráti kapcsolat és a részükrôl }\end{array}$ & 5,067 & 5,083 & $\mathbf{- 6 , 7 0 3}$ &, 460 & & & \\
megnyilvánuló támogatás & $\mathbf{8 , 6 3 7}$ & 1,170 & $\mathbf{- 2 , 4 5 3}$ & $\mathbf{4 , 4 7 8}$ &, 519 & & \\
6. Anyával és apával való kapcsolat & $\mathbf{1 1 , 3 9 6}$ & $\mathbf{3 , 2 4 2}$ & $\mathbf{- 5 , 3 0 5}$ & $\mathbf{2 , 6 0 7}$ & $\mathbf{2 , 5 9 4}$ &, 561 & \\
minôsége & $\mathbf{6 , 6 6 0}$ & $\mathbf{1 6 , 5 3 7}$ & $\mathbf{- 1 , 9 0 7}$ & $\mathbf{1 0 , 0 0 8}$ & $\mathbf{6 , 3 6 0}$ & $\mathbf{2 , 4 2 6}$ &, 515 \\
7. Altruizmus & & & & & & & \\
\hline
\end{tabular}

Megjegyzés: Félkövér $\rightarrow \mathrm{p}<, 05 ;$ Dôlt $\rightarrow$ másodrendû faktorba való töltés mértéke

\section{Nemi különbségek vizsgálata az életstratégia, a reziliencia és a szorongásérzékenység vonatkozásában $(H 1)$}

Az életstratégiában, rezilienciában és szorongásérzékenységben megmutatkozó nemi különbségek vizsgálatához a Mann-Whitney-próbát alkalmaztuk. Az eredmények alapján (2. táblázat) megállapíthatjuk, hogy a vizsgált mintában a nôk és a férfiak szorongásérzékenység-értékei nem különböznek egymástól. Az életstratégiát vizsgálva azonban szignifikáns nemi különbség mutatkozik. A nôk jelentôsen magasabb K-SF-42 összesített pontszámai a K-stratégia fokozottabb alkalmazására utalnak. Az alfaktorok különbségei alapján a közösségépítô, valamint a hosszú távú, megbízható családi és baráti kapcsolatokban jobban érdekeltek a nôk, ezekben altruizmusukat és spiritualitással kapcsolatos igényeiket is kifejezésre juttathatják. A reziliencia összesített pontszámaiban szintén nincs szignifikáns nemi különbség. A nehézségekkel szembenézô, kompetens belsố kontrollra építô sajátosságok tekintetében a két nem nagy fokú azonosságot mutat. Ugyanakkor a reziliencia faktorait vizsgálva megállapítható, hogy a nôk jelentôsen magasabb pontértéket érnek el a Szociális háttértámogatás biztosítása és az Értelemkeresés, spiritualitás faktorokon. Az adatelemzésben elsôsorban a reziliencia értelmezési keretét hangsúlyozzuk ki. Az adatok nemzetközi összehasonlíthatósága érdekében az alkalmazott mintára meghatároztuk a reziliencia magyar egyetemista populációra vonatkozó átlagértékét is. 670 egyetemi hallgató (életkori átlag $=25,7$; medián $=22,0 ; 18$ és 49 éves kor között) esetén a reziliencia átlagértéke 68,7; szórása 13,5; míg mediánja 70,0. Részletes adatokért lásd a 4. táblázatot. 


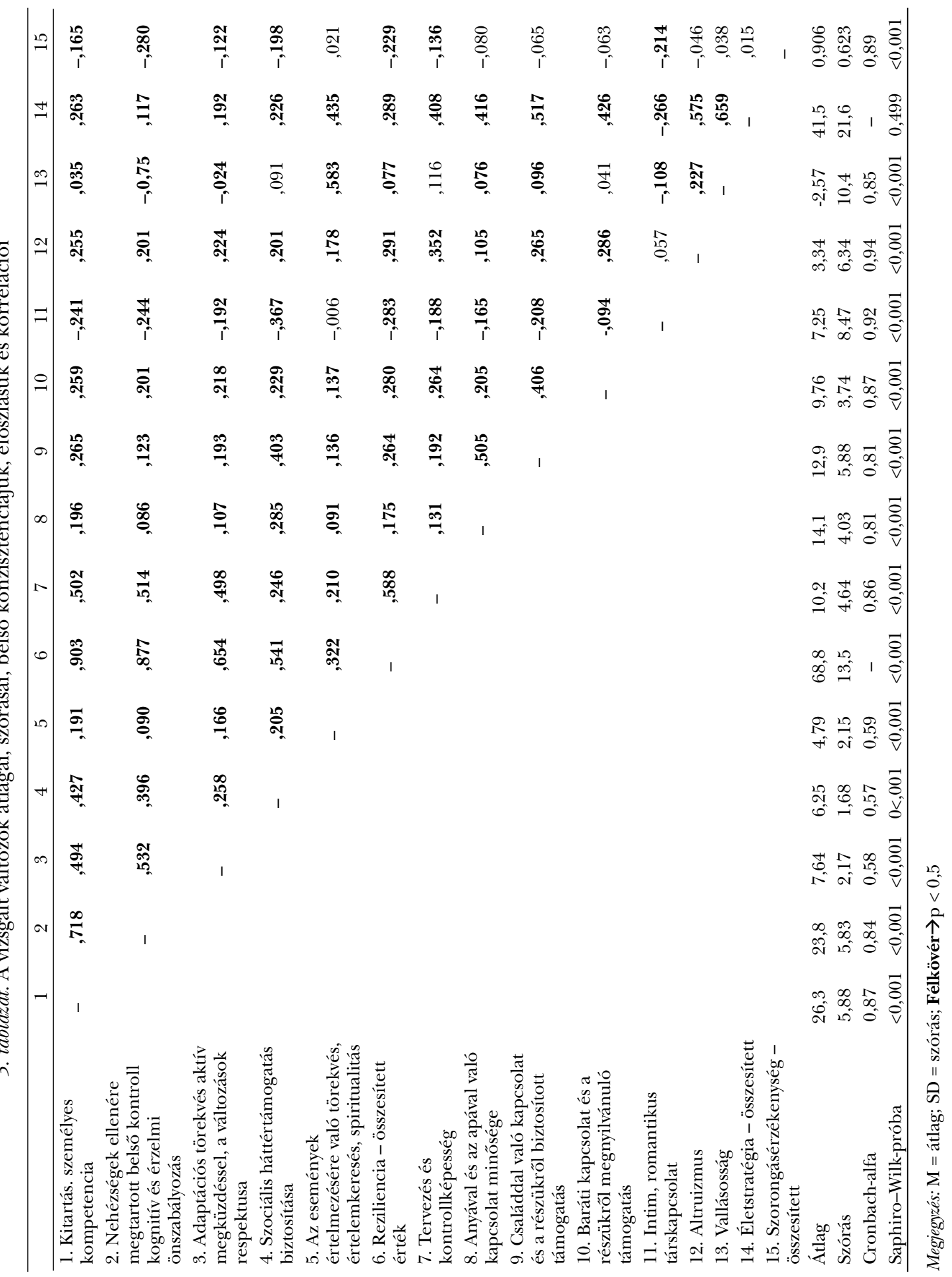


4. táblázat. A vizsgált változók átlagai és szórásai nemenkénti bontásban

\begin{tabular}{|c|c|c|c|c|c|c|c|c|}
\hline & \multicolumn{2}{|c|}{$\begin{array}{c}\text { Férfi } \\
(\mathrm{N}=191)\end{array}$} & \multicolumn{2}{|c|}{$\begin{array}{c}\text { Nố } \\
(\mathrm{N}=474)\end{array}$} & \multicolumn{2}{|c|}{ Mann-Whitney } & \multicolumn{2}{|c|}{ Hatásnagyság } \\
\hline & $\mathrm{M}$ & SD & $\mathrm{M}$ & SD & $\bar{U}$ & $\mathrm{p}$ & $\begin{array}{c}\text { Éta- } \\
\text { négyzet }\end{array}$ & $\begin{array}{l}\text { Cohen- } \\
\text { féle d }\end{array}$ \\
\hline 1. Kitartás, személyes kompetencia & 25,8 & 5,92 & 26,5 & 5,85 & 41188 & 0,085 & 0,0042 & 0,1298 \\
\hline $\begin{array}{l}\text { 2. Nehézségek ellenére megtartott } \\
\text { belsô kontroll, kognitív és érzelmi } \\
\text { önszabályozás }\end{array}$ & 24,4 & 6,01 & 23,6 & 5,75 & 42256 & 0,179 & 0,0038 & 0,1243 \\
\hline $\begin{array}{l}\text { 3. Adaptációs törekvés aktív } \\
\text { megküzdéssel, a változások } \\
\text { respektusa }\end{array}$ & 7,77 & 2,23 & 7,59 & 2,14 & 42670 & 0,242 & 0,0017 & 0,0816 \\
\hline $\begin{array}{l}\text { 4. Szociális háttértámogatás } \\
\text { biztosítása }\end{array}$ & 5,70 & 1,90 & 6,48 & 1,53 & 34477 & $<0,001$ & 0,0526 & 0,4712 \\
\hline $\begin{array}{l}\text { 5. Az események értelmezésére } \\
\text { való törekvés, értelemkeresés, } \\
\text { spiritualitás }\end{array}$ & 3,83 & 2,22 & 5,18 & 1,99 & 29566 & $<0,001$ & 0,0976 & 0,6576 \\
\hline 6. Reziliencia - összesített érték & 67,4 & 13,6 & 69,4 & 13,5 & 41354 & 0,081 & $-0,0734$ & 0,1468 \\
\hline 7. Tervezés és kontrollképesség & 9,81 & 4,55 & 10,3 & 4,67 & 35524 & 0,166 & 0,0031 & 0,1120 \\
\hline $\begin{array}{l}\text { 8. Az anyával és az apával való } \\
\text { kapcsolat minôsége }\end{array}$ & 13,8 & 4,07 & 14,2 & 4,01 & 35134 & 0,146 & 0,0029 & 0,1086 \\
\hline $\begin{array}{l}\text { 9. Családdal való kapcsolat és a } \\
\text { részükrôl biztosított támogatás }\end{array}$ & 11,8 & 5,72 & 13,5 & 5,89 & 31353 & $<0,001$ & 0,021 & 0,2931 \\
\hline $\begin{array}{l}\text { 10. Baráti kapcsolat és a részükrôl } \\
\text { megnyilvánuló támogatás }\end{array}$ & 8,83 & 3,83 & 10,2 & 3,63 & 30232 & $<0,001$ & 0,0322 & 0,3648 \\
\hline $\begin{array}{l}\text { 11. Intim, romantikus } \\
\text { társkapcsolat }\end{array}$ & 7,03 & 7,95 & 7,35 & 8,70 & 27564 & 0,558 & 0,0004 & 0,0381 \\
\hline 12. Altruizmus & 1,21 & 6,80 & 4,30 & 5,89 & 28457 & $<0,001$ & 0,0587 & 0,4994 \\
\hline 13. Vallásosság & $-4,91$ & 10,9 & $-1,52$ & 10,0 & 30612 & $<0,001$ & 0,0265 & 0,3298 \\
\hline 14. Életstratégia - összesített & 34,4 & 22,4 & 44,7 & 20,5 & 27064 & $<0,001$ & 0,0565 & 0,4894 \\
\hline $\begin{array}{l}\text { 15. Szorongásérzékenység - } \\
\text { összesített }\end{array}$ & 0,97 & 0,62 & 0,97 & 0,63 & 41640 & 0,625 & 0,0002 & 0,0274 \\
\hline
\end{tabular}

Megjegyzés: Félkövér $\rightarrow \mathrm{p}<0,5$

\section{A reziliencia, a szorongásérzékenység és az életstratégia összefüggései (H2)}

A reziliencia, a szorongásérzékenység és az életstratégiák közötti együtt járás vizsgálatára Spearman korrelációs eljárást alkalmaztunk. A gyújtôváltozók vizsgálata esetén gyenge pozitív kapcsolat mutatkozott az életstratégia és a reziliencia között $\left(r_{s}=0,289\right.$; $\mathrm{p}<0,001$ ), illetve szintén gyenge, ám negatív kapcsolat az életstratégia és a szorongásra való érzékenység között $\left(\mathrm{r}_{\mathrm{s}}=-0,229 ; \mathrm{p}<0,001\right)$. A reziliencia és a szorongásérzékenység között nem volt szignifikáns együtt járás $\left(r_{s}=0,015 ; p=0,724\right)$.

\section{A reziliencia mértékét elörejelzö konstruktumok vizsgálata (H3)}

Annak vizsgálatára, hogy mely változók jósolják be szignifikánsan a rezilienciát, hierarchikus lineáris regresszióanalízist alkalmaztunk az Enter-módszer használatával. 
5. táblázat. A hierarchikus lineáris regresszióelemzés vizsgálati modelljeinek áttekintése

\begin{tabular}{ccccccccccccc} 
& $\mathrm{R}$ & $\mathrm{R}^{2}$ & $\mathrm{aR}^{2}$ & $\Delta \mathrm{R}^{2}$ & $\mathrm{p}^{\Delta \mathrm{R} 2}$ & $\mathrm{AIC}$ & $\mathrm{BIC}$ & $\mathrm{RMSE}$ & $\mathrm{F}$ & $\mathrm{df1}$ & $\mathrm{df2}$ & $\mathrm{p}^{\mathrm{F}}$ \\
\hline M1 & 0,048 & 0,002 & 0,001 & - & - & 3914,3 & 3926,8 & 13,268 & 1,317 & 1 & 486 & $>0,050$ \\
M2 & 0,175 & 0,030 & 0,026 & 0,025 & $<0,001$ & 3902,1 & 3918,9 & 13,077 & 7,722 & 2 & 485 & $<0,001$ \\
M3 & 0,660 & 0,436 & 0,436 & 0,406 & $<0,001$ & 3651,1 & 3967,2 & 9,968 & 41,208 & 9 & 478 & $<0,001$ \\
\hline
\end{tabular}

Megjegyzés: AIC - Akaike információs kritérium; BIC - Bayes-féle információs kritérium; RMSE - négyzetes középérték hiba

A változók közötti multikollinearitás ellenôrzésére a varianciainflációs tényezô (VIF) értékeket vettük figyelembe, melyek a vizsgálatunk esetén 1,116 és 1,784. Ismételten három modell megalkotására került sor: az elsôben (M1) magyarázó változóként csupán a nem jelent meg, majd a második modellben (M2) ezt egészítette ki a szorongásérzékenység, míg végül harmadik lépésben (M3) kerültek bevonásra az életstratégia komponensei. Ahogy azt az 5. táblázatban is láthatjuk, az M1 nem bizonyult szignifikánsnak, míg a másik kettô igen. Ezek közül a harmadik modell bírt a legnagyobb magyarázó erôvel, így ezt tekintettük a végleges verziónak $\left[R=0,660 ; R^{2}=0,436 ; a R^{2}\right.$ $=0,436 ; \mathrm{RMSE}=9,968 ; \mathrm{F}(9,478)=41,208 ; \mathrm{p}<0,001]$. A modellek szignifikáns együtthatóit vizsgálva láthatjuk (6. táblázat), hogy az M2 esetén gyenge, negatív irányú prediktornak bizonyult a szorongásérzékenység $(\beta=-, 168)$, míg a harmadik modellben a szorongásérzékenység igen gyenge, majdhogynem jelentéktelen hatása mellett $(\beta=-, 076)$ szerepet kapott a tervezés és kontrollképesség $(\beta=, 519)$, míg kisebb súlylyal ugyancsak jelen voltak az intim, romantikus társkapcsolatok $(\beta=, 153)$, a családdal való kapcsolat és a részükrôl biztosított támogatás szerepe $(\beta=, 092)$, valamint a baráti kapcsolatok és a részükrôl megnyilvánuló támogatás $(\beta=, 084)$. A szorongásérzékenységet leszámítva minden összefüggés pozitív irányúnak bizonyult, míg a tervezés és kontrollképességét leszámítva (amely közepes mértéket mutatott), minden hatásnagyság alacsony szintûnek mutatkozott. További részletekért ld. a 6. táblázatot.

6. táblázat. A rezilienciát magyarázó változók

\begin{tabular}{llrrrrr} 
& Komponens & $\mathrm{B}$ & $\beta$ & $\mathrm{CI}^{\beta}$ & $\mathrm{t}$ & $\mathrm{p}$ \\
\hline $\mathrm{M} 1$ & Nem & 1,385 &, 104 & $-0,088-0,296$ & 1,063 & $>0,050$ \\
\hline \multirow{2}{*}{$\mathrm{M} 2$} & Nem & 1,392 &, 104 & $-0,085-0,294$ & 1,084 & $>0,050$ \\
& Szorongásérzékenység & $\mathbf{- 3 , 6 1 6}$ & $-\mathbf{1 6 8}$ & $\mathbf{- 0 , 2 5 6}-\mathbf{- 0 , 0 8 1}$ & $\mathbf{- 3 , 7 7 9}$ & $<\mathbf{0 , 0 0 1}$ \\
\hline & Nem & $-0,233$ &,- 017 & $-0,168-0,133$ & $-0,227$ & $>0,050$ \\
& $\begin{array}{l}\text { Szorongásérzékenység } \\
\text { Tervezés és kontrollképesség }\end{array}$ & $\mathbf{- 1 , 6 3 7}$ & $\mathbf{- , 0 7 6}$ & $\mathbf{- 0 , 1 4 5}-\mathbf{- 0 , 0 0 7}$ & $\mathbf{- 2 , 1 6 3}$ & $<\mathbf{0 , 0 5 0}$ \\
& $\mathbf{1 , 4 7 7}$ & $\mathbf{, 5 1 9}$ & $\mathbf{0 , 4 4 5 - 0 , 5 9 3}$ & $\mathbf{1 3 , 7 3 6}$ & $<\mathbf{0 , 0 0 1}$ \\
& $\begin{array}{l}\text { Anyával és az apával való kapcsolat } \\
\text { minốsége }\end{array}$ & 0,001 &, 014 & $-0,007-0,077$ & 0,014 & $>0,050$ \\
M3 & $\begin{array}{l}\text { Családdal való kapcsolat és a } \\
\text { részükról biztosított támogatás }\end{array}$ & $\mathbf{0 , 2 0 8}$ & $\mathbf{, 0 9 2}$ & $\mathbf{0 , 0 0 8 - 0 , 1 7 6}$ & $\mathbf{2 , 1 7 5}$ & $<\mathbf{0 , 0 5 0}$ \\
& $\begin{array}{l}\text { Baráti kapcsolat és a részükról } \\
\text { megnyilvánuló támogatás }\end{array}$ & $\mathbf{0 , 2 9 9}$ & $\mathbf{, 0 8 4}$ & $\mathbf{0 , 0 0 7 - 0 , 1 6 1}$ & $\mathbf{2 , 1 6 7}$ & $<\mathbf{0 , 0 5 0}$ \\
& $\begin{array}{l}\text { Intim, romantikus társkapcsolat } \\
\text { Altruizmus }\end{array}$ & $\mathbf{0 , 2 4 4}$ & $\mathbf{, 1 5 3}$ & $\mathbf{0 , 0 8 1 - 0 , 2 2 5}$ & $\mathbf{4 , 1 9 6}$ & $<\mathbf{0 , 0 0 1}$ \\
& Vallásosság & 0,079 &, 038 & $-0,038-0,115$ & 0,977 & $>0,050$ \\
& 0,032 &, 025 & $-0,045-0,096$ & 0,696 & $>0,050$ \\
\hline
\end{tabular}

Megjegyzés: Félkövér $\rightarrow \mathrm{p}<, 05 ; \mathrm{CI}-$ konfidenciaintervallum 


\section{MEGVITATÁS}

Tanulmányunkban elsôsorban a reziliencia mint a nehéz élethelyzetekhez való alkalmazkodást elôsegítô személyiségváltozó és az egyénre jellemzô életstratégia különbözố aspektusainak összefüggéseit kívántuk feltárni. Vizsgálataink kiterjedtek a szorongásérzékenységre és ennek a rezilienciával és az életstratégiával való kapcsolatára is. Emellett feltártuk a vizsgált változók esetében mutatkozó nemi különbségeket. A feltevéseink ellenôrzése érdekében az életstratégia felmérésére a K-SF-42 kérdőívet használtuk, amelynek skálaszerkezete megfeleló illeszkedési mutatókkal rendelkezett, így az eredetihez nagyban hasonló faktorszerkezet alkalmazása mellett döntöttünk. A 42. tétel nem mutatott szignifikáns töltést egyik faktor esetén sem, ezért a jövôbeni kutatások során érdemes megvizsgálni ennek okait és például alternatív fordítások bevonásával tesztelni a magyar nyelvú adaptáció érvényességét. Fontos továbbá kiemelnünk, hogy a kérdôív eredeti verziójával analóg módon korreláló faktorstruktúrát feltételeztünk, amely igazolást is nyert a másodrendú faktor bevonásával. Ugyanakkor, ahogy az a kovarianciamátrixból is kiolvasható, ezek értéke alacsony vagy maximum közepes mértékú, illetve adott esetben nem érik el szignifikancia határát. Ennek tisztázása további kutatásokat igényel: egyik alternatív hipotézisünk a kérdéskör magyarázatára a fiatalfelnôtt-populáció fejlődéslélektani sajátosságait helyezné a fókuszba, amely szélesebb körú mintavételezéssel - vagy akár célzott korosztályi kontrollcsoport bevonásával - lehetne kivitelezhetô. Összességében ugyanakkor elmondható, hogy a fentiekben bemutatott módon kialakított faktorszerkezet képes megragadni az élettörténeti stratégia különböző aspektusait.

A nemzetközi tanulmányok a reziliencia átlagértékeiben a nemi különbségekre vonatkozóan ellentmondó adatokat közölnek. Kínai, dél-koreai és kanadai medikusok a medikáknál lényegesen magasabb reziliencia-pontszámmal rendelkeznek (Peng és mtsai, 2012; Kang, Kim, Song, Namkoong és An, 2013; Rahimi, Baetz, Bowen és Balbuena, 2014). Ausztráliában viszont a fiatal nók mutatnak a férfiaknál magasabb rezilienciaszintet (Ziaian, De Anstiss, Antoniou, Baghurst és Sawyer, 2012). A reziliencia nemi különbségeit az élethelyzet, az anyagi boldogulás, iskolázottság, életkor, kulturális szokásrendszer is befolyásolja (Boell, Da Silva és Hegadoren, 2016). A nemi különbségek tekintetében tehát nincs egységes álláspont. Saját adataink szerint az egyetemistákból álló mintán nincs szignifikáns nemi különbség, de a nôk tendenciaszinten magasabb rezilienciáról számolnak be.

Az életstratégia vonatkozásában a nemi különbségek vizsgálata a nôk esetében jelzett nagyobb fokú közösségszervezô erôt és a biztonsági bázis megteremtésre való erôsebb igényt, de az életstratégia összesített pontszámának magasabb értékei a barátokkal való szorosabb kapcsolatban és az altruista attitúdben is tükrözôdnek. A magas életstratégia pontértékkel rendelkezô nôkrôl (lassú stratégia) a korábbi vizsgálatok már megállapították, hogy az életkilátásaik jobbak, a társak irányában kevésbé agreszszívek, a gyermekhalálozás a családjukban kisebb mértékú, többségében házasságban élnek, a válások száma esetükben alacsonyabb (Cabeza, és Figueredo, 2014). Emellett általában jelentôs mentális erôforrásokat fektetnek a család egységét biztosító céljaik megvalósításába. Ez a stratégia stabil és biztonságos körülmények között élô személyek számára biztosítja a közösség fennmaradását, és a hozzátartozó gyermekek számára 
az anyagi és intellektuális boldogulást. A gyors stratégia használata inkább a bizonytalan, perspektívák nélküli populációkra jellemzô (Figueredo és mtsai, 2005). Adataink egyértelmúen bizonyítják, hogy ezek az alapvetô proszociális vonások és motivációk a K-stratégia megvalósítását erôsítik. A fentebb említett nemi különbségek utalhatnak arra, hogy a vizsgálatban részt vevô fiatal egyetemista nôk a férfiakhoz képest nagyobb mértékben a K-típusú, lassú, közösségfejlesztésre, romantikus párkapcsolatok kialakítására és a biztonságos társas közeg megtartására összpontosító életstratégiát követnek. Korrelációs eredményeink pedig igazolják, hogy a hosszú távú reprodukciós sikerre számító személyek - nôk és férfiak egyaránt - nagyobb mértékben reziliensek.

Megvizsgáltuk, hogy a reziliencia összesített pontszáma ismeretében milyen predikciókat tehetünk a rövid vagy a hosszabb távra berendezkedô reprodukciós erôfeszítések vonatkozásában. Az elemzéseink megerôsítették a vizsgált változók közötti pozitív összefüggést, vagyis igazolták, hogy a nagyobb fokú rezilienciával jellemezhetô személyekre inkább jellemzô a K-stratégia alkalmazása. Mindazonáltal a reziliencia és az életstratégia összetevôi közti kapcsolatok vizsgálata rámutatott, hogy a két konstruktum három szempont mentén kapcsolódik össze egymással, melyek (1) a stresszhelyzetekkel való aktív és kitartó problémafókuszú megküzdés, (2) a támogató szociális kapcsolatok és (3) az értelemkeresés és vallásosság/spiritualitás. A rezilienciával foglalkozó korábbi tanulmányok egyértelmúen alátámasztják, hogy a vonásszintû reziliencia összefügg az aktív, problémafókuszú megküzdéssel a kontrollálhatónak tûnô stresszhelyzetek esetében (pl. Campbell-Sills és mtsai, 2006; Li és Nishikawa, 2012). Hasonlóképpen bizonyítást nyert, hogy a lassabb életstratégiát választó személyekre jellemzôbbek az aktív megküzdési stratégiák és a problémák pozitív átértékelése (Van der Linden, és mtsai, 2018). A támogató szociális kapcsolatok erőforrásként funkcionálnak, és hozzájárulnak az egyéni rezilienciához (Masten, Best, és Garmezy, 1990; Pangallo, Zibarras, Lewis és Flaxman, 2015), emellett pedig az életstratégiához is szorosan kapcsolódnak, hiszen ahogyan korábban említettük, a lassabb stratégiát követôk szociábilisabbak és megbízhatóbbak (Sherman, Figueredo és Funder, 2013), illetve nagyobb fokú támogatást élveznek, amelyre szívesen támaszkodnak a stresszhelyzetekben az adott probléma megoldása érdekében (Del Giudice és mtsai, 2011). A két konstruktum harmadik érintkezési pontja az értelemkeresés és a spiritualitás, amelyek egyfelôl segíthetik a nehéz élethelyzetekkel való megküzdést, és hozzájárulnak a magasabb szintû rezilienciához (Masten és mtsai, 1990; Connor és Davidson, 2003; Ebrahimi, Keykhosrovani, Dehghani és Javdan 2012). Másrészt, a spiritualitás/vallásosság hosszú távon az életstratégia részét is képezi, ugyanis a lassabb életstratégiát követôkre nagyobb fokú spirituális/vallásos orientáció jellemzô (Gladden, Welch, Figueredo és Jacobs, 2009). A hierarchikus lineáris regresszióelemzés alapján elmondható továbbá, hogy a rezilienciát a következô változók predikálják: Tervezés és kontrollképessége, Intim, romantikus kapcsolatban való elkötelezôdés, Családdal való kapcsolat és a kapott támogatás, Barátokkal való kapcsolat és a kapott támogatás, valamint a Szorongásérzékenység. Úgy tûnik tehát, hogy a rezilienciát a lassú életstratégia elemei közül elsôsorban a jövôre vonatkozó tervezés és a célokkal összhangban lévố viselkedésszabályozás határozza meg. Emellett a K-stratégia szociális aspektusa - a különbözô kapcsolatok kialakításába és fenntartásába befektetett nagy mennyiségú energia és szükség esetén a kapcsolatokból érkezô támogatás felhasználása - szintén támogatja és predi- 
kálja a vonásszintû rezilienciát. A szociális tényezôk közül az Intim, romantikus társkapcsolat a legerôsebb bejósló tényezô, amely a vizsgálati személyek életkorában (tkp. fiatal felnôttkor) kitüntetett jelentôségú relációnak számít, és az eredmények szerint a kölcsönös bizalmon és intimitáson alapuló párkapcsolat nagyobb fokú rezilienciát valószínúsít. Eredményeink egyúttal alátámasztják Werner és Smith (1992, 2001) multidimenzionális rezilienciakoncepcióját is, mely szerint a rezilienciához a személyiségbôl fakadó védôfaktorokon túl (vizsgálatunkban a tervezés és kontrollképesség, valamint a szorongásérzékenység alacsony mértéke) a családi és a tágabb szociális környezettel összefüggô védôfaktorok (vizsgálatunkban a párkapcsolat, a családi és a baráti kapcsolatok minôsége és az ezekból kapott támogatás) szintén hozzájárulnak.

A reziliencia és az életstratégia összefüggéseit feltáró vizsgálatunk a biztató eredmények mellett természetesen limitációkkal is rendelkezik. Ezek közé tartozik mindenekelőtt a hozzáférhetôségi mintavétel, amely számottevốen korlátozza a vizsgálat eredményeinek általánosíthatóságát. A keresztmetszeti vizsgálati elrendezés egy további korlátja a vizsgálatunknak, tekintve, hogy nem ad lehetôséget ok-okozati következtetések levonására. Végül érdemes kiemelni, hogy a vizsgálatunk nem terjedt ki részletes szociodemográfiai és élettörténeti adatok gyüjtésére. Az olyan változók, mint a párkapcsolati státusz, a szocioökonómiai helyzet vagy a korai kedvezôtlen tapasztalatok és a késôbbi életszakaszok krízisei, feltehetôen befolyásolhatják a vizsgált változókat és ezek kapcsolatát, így a jövóbeni kutatásokban érdemes lehet ezeket figyelembe venni. Fontos továbbá kiemelnünk, hogy a feltárt összefüggések bár szignifikáns módon jelentek meg a vizsgálatunk eredményei között, azok hatásnagysága jellemzôen alacsony, ami felveti további pszichológiai konstruktumok lehetséges szerepét a reziliencia és az élettörténeti stratégiák közötti kapcsolat dinamikájában.

Vizsgálatunk eredményei összességében azt tükrözik, hogy magasabb rezilienciaértékek esetén a fiatal felnôttek lassabb életstratégiát követnek, amely a hosszú távú tervezésben, a célok követésében, kapcsolatok kialakításában és ezek ápolásában, vagy az események és az élet értelmének keresésében nyilvánul meg. A rezilienciájuk mértékét egyaránt meghatározzák személyiségbeli és szociális erôforrásaik. A magas szintû rezilienciával rendelkezô fiatalokra nemtôl függetlenül jellemzô az elôrelátó életvitel, a jövőre vonatkozó tervek, célok meghatározása, amelyekkel jelenlegi viselkedésük kongruens, illetve párkapcsolatukba sok energiát fektetnek, igyekeznek elkötelezett társkapcsolatot kialakítani. Mindezek alapján úgy tûnik, hogy a reziliens megküzdés elôsegítése érdekében a fiatal felnôttek esetében (csakúgy, mint más korcsoportokban is) érdemes lenne módot találni a hosszú távú céljaik definiálásának elôsegítésére, valamint annak támogatására, hogy a jelenben hogyan tudják a viselkedésüket a céljaikkal összhangban irányítani az esetleges stresszhelyzetekben (pl. fontos lehet az egyetemi képzésbe integrálni jövôtervezéssel, karriertervezéssel kapcsolatos kurzusokat, illetve az ilyen jellegú egyetemi tanácsadó szolgáltatásokat minél szélesebb körben elérhetôvé tenni). Tekintettel azonban arra, hogy mind a lassú, mind a gyors életstratégia adaptív lehet bizonyos életkörülmények között, így felvetôdik a kérdés, hogy a reziliencia és a lassú stratégia kapcsolata mennyiben reflektál a vizsgált minta feltehetôen viszonylag stabil és erôforrásokban gazdag élethelyzetére és optimista, lehetôségekben bôvelkedô, tervezhetô jövôképére. A késôbbiekben tehát érdemes lenne megvizsgálni, hogy a tartósan kedvezôtlen társadalmi-gazdasági körülmények között 
élố csoportokban hogyan függ össze a reziliencia és az életstratégia. További vizsgálati kérdés lehet a változók közötti összefüggés stabilitása és annak vizsgálata, hogy például az életkörülmények jelentôs megváltozása miként befolyásolja a kapcsolatukat.

\section{KÖSZÖNETNYILVÁNÍTÁS}

A tanulmányt az NKFI K 120334 pályázat és az Emberi Erôforrások Minisztériuma ÚNKP-18-3-IV-PTE-96 kódszámú Új Nemzeti Kiválóság Programja támogatta. Összeférhetetlenség nincs.

\section{IRODALOM}

Ahern, N. R., Kiehl, E. M., Sole, M. L., \& Byers, J. (2006). A review of instruments measuring resilience. Issues in Comprehensive Pediatric Nursing, 29(2), 103-125. DOI: $10.1080 / 01460860600677643$

Bereczkei, T. (2003). Evolúciós pszichológia. Osiris Kiadó: Budapest.

Bereczkei, T., Birkas, B., \& Kerekes, Z. (2007). Public charity offer as a proximate factor of evolved reputation-building strategy: an experimental analysis of a real-life situation. Evolution and Human Behavior, 28(4), 277-284. DOI: 10.1016/j.evolhumbehav.2007.04.002

Birkás, B., Pátkai, G., \& Csathó, Á. (2018). The mediating role of the dark triad between life history strategy and perceived stress factors. Psychological Reports, 2018. dec. 20. DOI: $10.1177 / 0033294118818095$

Boell, J. E. W., Da Silva, D. M. G. V., \& Hegadoren, K. M. (2016). Sociodemographic factors and health conditions associated with the resilience of people with chronic diseases: a cross sectional study. Revista Latino-Americana Enfermagem, 2016. sep. 01. DOI: $10.1590 / 1518-83451205.2786$

Buss, D. M. (1997). Evolutionary foundations of personality. In R. Hogan (Ed), Handbook of Personality Psychology (pp. 317-344.). London: Academic Press.

Cabeza, de Baca, T., \& Figueredo, A. J. (2014). The cognitive ecology of Mexico: climatic and socio-cultural effects on life history strategies and cognitive abilities. Intelligence, 47, 63-71. DOI: $10.1016 /$ j.intell.2014.08.007

Caffo, E., \& Belaise, C. (2003). Psychological aspects of traumatic injury in children and adolescents. Child and Adolescent Psychiatric Clinics of North America, 12(3), 493-535. DOI: 10.1016/ S1056-4993(03)00004-X

Campbell-Sills, L., Cohan, S. L., \& Stein, M. B. (2006). Relationship of resilience to personality, coping, and psychiatric symptoms in young adults. Behaviour Research and Therapy, 44(4), 585-599. DOI: 10.1016/j.brat.2005.05.001

Carle, A. C., \& Chassin, L. (2004). Resilience in a community sample of children of alcoholics: Its prevalence and relation to internalising symptomatology and positive affect. Journal of Applied Developmental Psychology, 25, 577-596. DOI: 10.1016/j.appdev.2004.08.005

Charney, D. S. (2004). Psychobiological mechanisms of resilience and vulnerability: Implications for adaptation to extreme stress. American Journal of Psychiatry, 161(2), 195-216. DOI: 10.1176/appi.ajp.161.2.195

Cohen, D. G., Christie, J. D., Anderson, B.J., Diamond,J. M., Judy, R. P., Shah, R.J. etal. (2014). Cognitive function, mental health, and health-related quality of life after lung transplant. Annals of the American Thoracic Society, 11, 522-530. DOI: 10.1513/AnnalsATS.201311-388OC 
Connor, K. M. \& Davidson, J. R. T. (2003). Development of a new resilience scale: the ConnorDavidson Resilience Scale (CD-RISC). Depression and Anxiety, 18(2), 71-82. DOI: 10.1002/ da.10113

Davidson, J. R. T., \& Connor, K. M. (2017). Connor-Davidson Resilience Scale (CD-RISC) Manual. Unpublished. Partly accessible at www.cd-risc.com.

De Robert, S. C., Barontini, M., Forcada, P., Carrizo, P., \& Almada, L. (2010). Psychological stress and low resilience: a risk factor for hypertension. Cardiovascular Prevention, 78(5). 425-431.

Deacon, B., \& Abramowitz, J. S. (2006). Anxiety sensitivity and its dimensions across the anxiety disorders. Journal of Anxiety Disorders, 20(7), 837-857. DOI: 10.1016/j.janxdis.2006.01.003

Del Giudice, M., Ellis, B. J., \& Schirtcliff, E. A. (2011). The adaptive calibration model of stress responsivity. Neuroscience and Behavioral Reviews, 35(7), 1562-1592. DOI: 10.1016/j. neubiorev.2010.11.007

Ebrahimi, A., Keykhosrovani, M., Dehghani, M., \& Javdan, M. (2012). Investigating the relationship between resiliency, spiritual intelligence and mental health of a group of undergraduate students. Life Science Journal, 9(1), 67-70.

Field, C., \& Smith, B. (1994). Robust Estimation - A Weighted Maximum Likelihood Approach. International Statistical Review, 62(3), 405-424.

Figueredo, A. J., Garcia, R. A., Menke, J. M., Jacobs, W. J., Gladden, P. R., Bianchi, J. M., Patch, E. A., Beck, C. J. A., Kavanagh, P. S., Sotomayor-Peterson, M., Jiang, Y., \& Li, N. P. (2017). The K-SF-42: A new short form of the Arizona Life History Battery. Evolutionary Psychology, 15(1), 1-12. DOI: $10.1177 / 1474704916676276$

Figueredo, A. J., Vásquez, G., Brumbach, B. H., Schneider, S. M. R., Sefcek, J. A., Tal, I. R., et al. (2006). Consilience and life history theory: From genes to brain to reproductive strategy. Developmental Review, 26(2), 243-275. DOI: 10.1016/j.dr.2006.02.002

Figueredo, A. J., Sefcek, J. A., Vásquez, G., Brumbach, B. H., King, J. E., \& Jacobs, W. J. (2005). Evolutionary personality psychology. In D. Buss (Ed), The Handbook of Evolutionary Psychology (pp. 851-877.). Hoboken, NJ: Wiley.

Figueredo, A. J., Wolf, P. S. A., Gladden, P. R., Olderbak, S. G., Andrzejczak, D. J. \& Jacobs, W. J. (2010). Ecological approaches to personality. In D. M. Buss \& P. H. Hawley (Eds), The Evolution of Personality and Individual Differences (pp. 210-239.). New York, NY: Oxford University Press.

Figueredo, A. J., Woodley of Menie, M. A. \& Jacobs, W. J. (2015). The general factor of personality: A hierarchical life history model. In D. Buss (Ed), Handbook of Evolutionary Psychology, 2nd ed., vol. 2: Integrations (pp. 943-967.). New York, NY: Wiley.

Gladden, P. R., Welch, J., Figueredo, A. J., \& Jacobs, W. J. (2009). Moral intuitions and religiosity as spuriously correlated life history traits. Journal of Evolutionary Psychology, 7(2), 167-184. DOI: 10.1556/JEP.7.2009.2.5

Haskett, E., Nears, K., Ward, S., \& McPherson, A. V. (2006). Diversity in adjustment of maltreated children: Factors associated with resilient functioning. Clinical Psychology Review, 26(6), 796-812. DOI: 10.1016/j.cpr.2006.03.005

Jonason, P. K., Koenig, B. L., \& Tost, J. (2010). Living a fast life. Human Nature, 21(4), 428-442. DOI: $10.1007 / \mathrm{s} 12110-010-9102-4$

Kalantar, A., Bigdeli, I., Mashhadi, A., Karekshi, H. (2019). Modeling Structural Equations of Anxiety Sensitivity, Emotion Regulation and Resilience in the Formation of Depression and PTSD Disorders in Firefighters. Journal of Clinical Psychology, 11(2), 90-103. DOI: 10.22075/ JCP.2019.17896.1682.

Kang, J. I., Kim, S. J., Song, Y. Y., Namkoong, K., \& An, S. K. (2013). Genetic influence of COMT and BDNF gene polymorphisms on resilience in healthy college students. Neuropsychobiology, 68(3), 174-180. DOI: $10.1159 / 000353257$ 
Kállai, J. (2013). Társas kapcsolatok neuropszichológiája. Budapest: Medicina Kiadó.

Kerekes, Zs. (2012). A szorongás, mint adaptív viselkedés. A szorongásérzékenység mérésének tapasztalatai különbözố csoportoknál. (PhD-disszertáció) Pécs: PTE BTK.

Kiss, E. CS., Vajda, D., Káplár, M., Csókási, K., Hargitai, R., \& Nagy L. (2015). A 25-itemes Connor-Davidson Rezíliencia Skála (CD-RISC) magyar adaptációja. Mentálhigiéné és Pszichoszomatika, 1, 93-113. DOI: 10.1556/Mental.16.2015.1.4

Lebeaut, A., Tran, J. K., Vujanovic, A. A. (2020). Posttraumatic stress, alcohol use severity, and alcohol use motives among firefighters: The role of anxiety sensitivity. Addictive Behaviors, 106, 106353. DOI: 10.1016/j.addbeh.2020.106353.

Li, M. H., \& Nishikawa, T. (2012). The relationship between active coping and trait resilience across US and Taiwanese college student samples. Journal of College Counseling, 15(2), 157-171. DOI: 10.1002/j.2161-1882.2012.00013.x

Lies, J., Lau, S. T., Jones, L. E., Jensen, M. P., Tan, G. (2017). Predictors and Moderators of Post-traumatic Stress Disorder: An Investigation of Anxiety Sensitivity and Resilience in Individuals with Chronic Pain. Annals of the Academy of Medicine, Singapore, 46(3), 102-110.

Masten, A. S., Best, K. M., \& Garmezy, N. (1990). Resilience and Development: Contributions from the Study of Children Who Overcome Adversity. Development and Psychopathology, 2, 425-444. DOI: $10.1017 /$ S0954579400005812

Marulanda, S, \& Addington J. (2014). Resilience in individuals at clinical high risk for psychosis. Early Intervention in Psychiatry, 10(3), 1-8. DOI: 10.1111/eip.12174

McDonald, M. M., Donnellan, M. B., \& Navarrete, C. D. (2012). A life history approach to understanding the Dark Triad. Personality and Individual Differences, 52(5), 601-605.

Norris, F. H., Stevens, S. P., Pfefferbaum, B., Wyche, K. F., \& Pfefferbaum, R. L. (2008). Community resilience as a metaphor, theory, set of capacities, and strategy for disaster readiness. American Journal of Community Psychology, 41(1-2), 127-150. DOI: 10.1007/s10464-007-9156-6

Otto, M. W., Eastman, A., Lo, S., Hearon, B. A., Bickel, W. K., Zvolensky, M., Smits, J. A. J., Doan, S. N. (2016). Anxiety sensitivity and working memory capacity: Risk factors and targets for health behavior promotion. Clinical Psychology Review, 49, 67-78. DOI: 10.1016/j. cpr.2016.07.003.

Pangallo, A., Zibarras, L., Lewis, R., \& Flaxman, P. (2015). Resilience through the lens of interactionism: A systematic review. Psychological Assessment, 27(1), 1-20. DOI: 10.1037/ pas0000024

Paulus, D. J., Zvolensky, M. J. (2020). The prevalence and impact of elevated anxiety sensitivity among hazardous drinking college students. Drug and Alcohol Dependence, 209, 107922. DOI: 10.1016/j.drugalcdep.2020.107922.

Peng, L., Zhang, J., Li, M., Zhang, Y., Zuo, X., Miao, Y., \& Xu Y. (2012). Negative life events and mental health of Chinese medical students: the effect of resilience, personality and social support. Psychiatry Research, 196(1), 138-141. DOI: 10.1016/j.psychres.2011.12.006

Poole, J. C, Dobson, K. S, \& Pusch, D. (2017). Anxiety among adults with a history of childhood adversity: Psychological resilience moderates the indirect effect of emotion dysregulation. Journal of Affective Disorders, 217, 144-152. DOI: 10.1016/j.jad.2017.03.047

Rahimi, B., Baetz, M., Bowen, R., \& Balbuena, L. (2014). Resilience, stress, and coping among Canadian medical students. Canadian Medical Education Journal, 5(1), e5-e12.

Reiss, S., Peterson, R. A., Gursky, D. M., \& McNally, R. J. (1986). Anxiety sensitivity, anxiety frequency, and the prediction of fearfulness. Behavior Research and Therapy, 24(1), 1-8.

Schmitt, D. P., Long, A. E., Mcphearson, A., O'Brien, K., Remmert, B. \& Shah, S. H. (2017). Personality and gender differences in global perspective. International Journal of Psychology, 52(1), 45-56. DOI: 10.1002/ijop.12265 
Sexton, M. B., Hamilton, L., McGinnis, E. W., Rosenblum, K. L., \& Muzik, M. (2015). The roles of resilience and childhood history: Main and moderating effects on postpartum maternal mental health and functioning. Journal of Affective Disorders, 174, 562-568. DOI: 10.1016/j. jad.2014.12.036

Sherman, R. A., Figueredo, A. J., \& Funder, D. C. (2013). The behavioral correlates of overall and distinctive life history strategy. Journal of Personality and Social Psychology, 105(5), 873-888. DOI: $10.1037 / \mathrm{a} 0033772$

Tannenbaum, B., \& Anisman, H. (2003). Impact of chronic intermittent challenges in stressorsusceptible and resilient strains of mice. Biological Psychiatry, 53(4), 292-303.

Tops, M. (2014). Slow life strategies and slow updating of internal models: The examples of consciousness and obsessive compulsive disorder. Psychological Inquiry, 25(3-4), 376-384. DOI: 10.1080/1047840X.2014.916194

Van der Linden, D., Dunkel, C. S., Tops, M., Hengartner, M. P., \& Petrou, P. (2018). Life history strategy and stress: An effect of stressful life events, coping strategies, or both? Personality and Individual Differences, 135, 277-285. DOI: 10.1016/j.paid.2018.07.024

Werner, E. E., \& Smith, R. S. (1992). Overcoming the odds: High risk children from birth to adulthood. Ithaca, NY: Cornell University Press.

Werner, E. E., \& Smith, R. S. (2001). Journeys from childhood to midlife: Risk, resilience, andrecovery. Ithaca, NY: Cornell University Press.

Ziaian, T., De Anstiss, H., Antoniou, G., Baghurst, P., \& Sawyer, M. (2012). Resilience and its association with depression, emotional and behavioural problems, and mental health service utilization among refugee adolescents living in South Australia. International Journal of Population Research, Article ID 485956. DOI: 10.1155/2012/485956 


\title{
THE ASSOCIATIONS BETWEEN RESILIENCE AND LIFE HISTORY STRATEGY AMONG UNIVERSITY STUDENTS
}

\author{
BANDI, SZABOLCS - CSÓKÁSI, KRISZTINA- \\ KÁLLAI, JÁNOS - TIRINGER, ISTVÁN - MARTIN, LÁSZLÓ - KISS, ENIKÓ CSILLA
}

Background and aims: The aim of the study is to explore the possible relationship among the so-called „slow”, „K” life history strategy, resilience and anxiety sensitivity. Although both constructs are well known and popular in their own disciplines, their interdisciplinary integration (evolutionary-, positive- and clinical psychology) is quite novel in the field of empirical research. In our study we would like to verify the positive interrelation between resilience and K-strategy.

Methods: A convenience sample of 674 undergraduate students participated in our, in which paperpencil-based self-report questionnaires have been applied to measure the above-mentioned constructs. Participants completed the Connor-Davidson Resilience Scale, the Life Strategy Questionnaire and the Anxiety Sensitivity Index.

Results: The correlations and linear regressions verified positive connection between resilience and $K$ strategy, while anxiety sensitivity showed negative interrelation. Gender differences have been identified, but the disproportionality of the sample did not allow us to interpret them in a coherent way.

Conclusions: Our results demonstrated a weak association between resilience and slow life strategy among young adults. More precisely, resilient students displayed better planning skills and reported stronger interpersonal relatinships with their family, peers and intimate partners. Although anxiety sensitivity at some points had significant effects on the variables, their effect size was pretty low. Furthermore, gender differences were revealed in resilience and life history strategy, but further studies are required to determine their relevance.

Keywords: resilience, life-strategy, planning skills, intimate relationships, anxiety sensitivity

A cikk a Creative Commons Attribution 4.0 International License (https://creativecommons. org/licenses/by/4.0) feltételei szerint publikált Open Access közlemény, melynek szellemében a cikk bármilyen médiumban szabadon felhasználható, megosztható és újraközölhetô, feltéve, hogy az eredeti szerzố és a közlés helye, illetve a CC License linkje és az esetlegesen végrehajtott módosítások feltüntetésre kerülnek. (SID_1) 